\title{
Discretie en feitenvaststelling in asielprocedures
}

\author{
Ralph Severijns
}

\section{Introductie}

Ambtenaren van de Immigratie- en Naturalisatiedienst (IND) hebben de haast onmogelijke taak om te bepalen wie recht heeft op asielbescherming in Nederland. Ik typeer dit selectieproces als 'haast onmogelijk' vanwege de hoge mate van bewijsonzekerheid die asielprocedures kenmerkt. In dit kwalitatieve rechtssociologische onderzoek, verricht aan het Centrum voor Migratierecht aan de Radboud Universiteit, ga ik na hoe deze ambtenaren uitvoering geven aan het asielrecht. Mijn centrale onderzoeksvraag is:

Hoe gaan ambtenaren van de IND in het asielrecht om met onzekerheid over de feiten?

In het onderzoek staat het proces van feitenvaststelling in asielprocedures vanuit het perspectief van de IND- ambtenaar centraal. Ik inventariseer welke verschillen in de uitvoeringspraktijk bestaan en welke verklaringen voor deze verschillen kunnen worden gevonden. Hierbij richt ik me vooral op de vraag hoe deze ambtenaren in het proces van feitenvaststelling in hun handelen worden beïnvloed door het recht, door de organisatorische context waarbinnen ze werken en hun eigen rolopvatting.

\section{Onzekerheid over de feiten}

In asielprocedures is het zo goed als onmogelijk om te weten of het genomen besluit ook het juiste besluit is. Hiermee wordt niet gedoeld op de vraag of het besluit al dan niet juridisch door de beugel kan, maar of de beslissing juist is gelet op het werkelijke gevaar dat een asielzoeker in zijn land van herkomst loopt. Hoewel waarheidsvinding in het recht in de meeste rechtsgebieden problematisch is, ben ik van mening dat weinig rechtsgebieden zozeer worden gekenmerkt door bewijsonzekerheid als het asielrecht. Enerzijds is deze bewijsonzekerheid inherent aan de te beantwoorden vraag, namelijk: heeft de asielzoeker in zijn land van herkomst gegrond te vrezen voor vervolging, of loopt hij daar een reëel risico op marteling, of een vernederende of onmenselijke behandeling of bestraffing? De kern van het asielrecht is dus de vraag of iemand in de toekomst gevaar loopt. De toekomst is per definitie onzeker en onmogelijk om te bewijzen. Een tweede omstandigheid die bewijsonzekerheid oplevert, is dat de inschatting of iemand in de toekomst gevaar loopt, inzicht vereist in de algemene situatie in het land van herkomst en in de individuele omstandigheden die voor de asielzoeker aanleiding hebben gevormd om zijn land van herkomst te verlaten. Aangezien deze gebeur- 
tenissen zich in landen hier ver vandaan hebben afgespeeld, vaak in oorlogs- of crisissituaties, is het anders dan bijvoorbeeld in het strafrecht niet mogelijk om getuigen te horen, forensisch onderzoek te doen, of op een andere wijze ter plekke bewijs te verzamelen van hetgeen de asielzoeker heeft meegemaakt. Daarnaast staat in asielprocedures vaak de vraag centraal of de asielzoeker van de autoriteiten van zijn land van herkomst heeft te vrezen, dus ook het opvragen van informatie bij deze autoriteiten is problematisch, zo niet onmogelijk.

Ten slotte is de bewijsonzekerheid inherent aan bepaalde feiten die relevant kunnen zijn voor de beoordeling van een asielaanvraag. Om te kunnen beoordelen of iemand in zijn land van herkomst vreest te worden vervolgd vanwege zijn geloofsovertuiging of seksuele gerichtheid, is het bijvoorbeeld (in beginsel) van belang te weten wat zijn geloofsovertuiging, of seksuele gerichtheid is. ${ }^{1}$ Het is maar de vraag of dit objectief kan worden vastgesteld. In de context van een asielprocedure lijkt mij dit in ieder geval niet goed mogelijk.

\section{Informatiebronnen}

Ondanks de hierboven genoemde onzekerheden moet iedere asielaanvraag leiden tot een besluit. Om een besluit te kunnen nemen zal de IND-ambtenaar de relevante feiten in de zaak moeten vaststellen. Hij zal de onzekerheid ten aanzien van deze feiten moeten verminderen tot een niveau dat voor hem acceptabel is en op basis van het totaal aan meer of minder zekere feiten een beslissing moeten nemen. Voor dit proces van verminderen van onzekerheden heeft hij informatie nodig. De drie belangrijkste informatiebronnen voor de IND-ambtenaar zijn de algemene ambtsberichten van het ministerie van Buitenlandse Zaken waarin de veiligheids- en mensenrechtelijke situatie in het land van herkomst wordt geschetst, de twee gehoren die de IND afneemt met de asielzoeker en eventueel beschikbare documenten die de identiteit en het asielrelaas van de asielzoeker kunnen onderbouwen zoals paspoort, huwelijksakte, reisbescheiden en zaken als arrestatiebevelen of rechterlijke uitspraken. Als deze drie bronnen onvoldoende zijn, kunnen IND-ambtenaren daarnaast gebruikmaken van deskundigenonderzoek zoals taalanalyse (om iemands herkomst vast te stellen), documentenonderzoek, leeftijdsonderzoek en onderzoek in het land van herkomst door (of via) Buitenlandse Zaken.

Al deze bronnen kunnen de onzekerheid over wat de asielzoeker heeft meegemaakt en de algemene situatie in het land van herkomst, in potentie, tot op zekere hoogte verminderen. Iedere informatiebron kent echter ook specifieke beperkingen. De deskundigen die door de IND kunnen worden ingeschakeld, worden niet altijd als objectief en onafhankelijk gezien en vakgenoten van deze deskundigen hebben soms kritiek op hun methode en vragen over de betrouwbaarheid van het deskundigenonderzoek. Daarnaast kan deskundigenonderzoek nooit volledig uitsluitsel geven, maar slechts waarschijnlijkheidsoordelen. De algemene

1 Hoewel ook de omstandigheid dat iemand in zijn land van herkomst door anderen wordt gezien als iemand met een afwijkende geloofsovertuiging of seksuele gerichtheid voldoende grond kan zijn voor een vrees voor vervolging. 
ambtsberichten van het ministerie van Buitenlandse Zaken zijn zeer algemeen van opzet en kunnen weinig zeggen over de beschermingsbehoefte van een individu.

De belangrijkste informatie ter beoordeling van de individuele beschermingsbehoefte zijn de verklaringen van de asielzoeker. Deze verklaringen worden, niet verwonderlijk, niet voetstoots voor waar aangenomen. Documenten die het relaas ondersteunen, ontbreken veelal. Asielzoekers kunnen om uiteenlopende redenen besluiten niet de (hele) waarheid te vertellen in een poging de kans op een verblijfsvergunning te vergroten. Daarnaast kunnen herinneringen onbewust zijn vertekend. Ook is het maar de vraag of de asielzoeker in staat is om onder alle omstandigheden een coherente verklaring af te leggen. ${ }^{2}$ De IND-ambtenaar heeft de taak zich een oordeel te vormen over de vraag of de verklaringen van de asielzoeker 'geloofwaardig' zijn.

Dit alles betekent niet dat er helemaal geen informatie beschikbaar is. Potentieel is er zelfs zeer veel informatie beschikbaar. Een google-zoekactie op 'violence in Somalia' levert 28 miljoen treffers op. Het is voor ambtenaren van de IND dus ook een kwestie van selecteren van informatie. Dat geldt overigens niet alleen voor informatie afkomstig uit openbare bronnen. Welke informatie uit een gehoor met een asielzoeker wordt verkregen, is bijvoorbeeld grotendeels afhankelijk van de vragen die de IND-ambtenaar stelt. De IND-ambtenaar heeft dus een belangrijke rol in het sturen van de informatievoorziening.

\section{Factoren die de omgang met onzekerheid over de feiten beïnvloeden}

Drie factoren zijn mijns inziens vooral van belang voor de vraag hoe IND-ambtenaren omgaan met onzekerheid over de feiten. De eerste factor is het recht. Het recht bepaalt allereerst wat bewezen moet worden: de bewijsomvang. Daarnaast schrijft het recht voor met welke mate van zekerheid bewezen moet worden: de bewijsstandaard. Ten derde biedt het recht normen voor de wijze waarop het proces van bewijsvoering moet worden ingericht en hoe de bewijslast moet worden verdeeld.

Om met het recht te kunnen werken zullen de betreffende juridische bepalingen door de IND als uitvoeringsorganisatie en door iedere individuele IND-ambtenaar moeten worden geïnterpreteerd. Er is dus discretionaire ruimte voor de uitvoeringsorganisatie en de uitvoerende ambtenaren. Door deze discretionaire ruimte hebben ambtenaren in de uitvoering onvermijdelijk keuzemogelijkheden. ${ }^{3} \mathrm{Als}$ verschillende ambtenaren in vergelijkbare situaties verschillende keuzes maken, zal dit tot rechtsongelijkheid leiden. ${ }^{4}$ Daar staat tegenover dat discretionaire ruimte ambtenaren de mogelijkheid geeft hun beslissing toe te spitsen op het individuele geval. De discretionaire ruimte wordt door de uitvoeringsorganisatie deels gestructureerd en verkleind door middel van formeel en informeel beleid, de organisatie van de werkprocessen, de instructies van managers, de taakverdeling,

2 Cohen 2002.

3 Hawkins 2001.

4 Kelly 2011. 
en de noodzaak om beslissingen van de organisatie te coördineren. ${ }^{5}$ Het is echter onvermijdelijk (en wellicht ook gewenst) dat individuele ambtenaren beoordelingsruimte en dus keuzemogelijkheden houden. ${ }^{6}$ Verschillende ambtenaren hanteren verschillende uitvoeringsstijlen, ${ }^{7}$ die bijvoorbeeld worden gevormd door verschillende routines, culturen, ervaring en opleiding. ${ }^{8}$ Hun handelingsvrijheid wordt beperkt door de beperkte middelen en tijd die zij ter beschikking hebben. Dat kan leiden tot dilemma's. ${ }^{9}$ Het onderzoek zal inzicht geven in de uitvoeringsstijlen die door IND-ambtenaren worden gehanteerd bij het vaststellen van de feiten en in de wijze waarop zij hun discretionaire ruimte invullen.

\section{Methode}

In het eerste deel van het onderzoek zal ik het geldende recht en de organisatorische context beschrijven waarbinnen de feitenvaststelling in asielprocedures moet plaatsvinden. Vervolgens wordt door middel van interviews en observatie de perspectieven van de individuele IND-ambtenaren onderzocht. Door deze perspectieven te analyseren wordt in kaart gebracht welke handelingsvrijheid verschillende typen ambtenaren ervaren. Tevens wordt nagegaan in hoeverre zij hun uitvoeringsstijl rechtvaardigen door verwijzing naar het recht, de organisatorische context waarbinnen ze werken en hun eigen rolopvatting. Ik verwacht op basis van dit materiaal niet alleen een typologie te kunnen maken van de perspectieven van ambtenaren, maar tevens verschillende typen feiten te kunnen onderscheiden ten aanzien waarvan in meer of minder mate vrijheid wordt ervaren om het proces van feitenvaststelling in te richten. In totaal zal ik 36 semigestructureerde interviews houden met hoor- en beslisambtenaren van de IND, verspreid over drie van de vier IND-locaties waar asielaanvragen worden behandeld. Voorafgaand aan het interview observeer ik de ambtenaar terwijl hij een eerste of nader gehoor met een asielzoeker afneemt. In het daaropvolgende interview bespreek ik alle stappen van de asielprocedure waarin de asielambtenaar een rol vervult en vraag hem hoe hij zijn rol opvat, hoe die rolopvatting zich door de jaren heen heeft ontwikkeld, welke keuzemogelijkheden hij heeft bij het uitvoeren van zijn rol en welke rechtvaardiging hij geeft voor zijn keuzes. Daarnaast ga ik in op de vraag hoe de ambtenaar omgaat met moeilijke gevallen, waarbij ik een aantal bekende categorieën van moeilijk vast te stellen feiten betrek. Ten slotte vraag ik de ambtenaar hoe hij wordt begeleid en gecontroleerd, waaruit zijn opleiding bestaat en hoe hij zichzelf positioneert ten opzichte van zijn collega's. De ambtenaren worden door mij geselecteerd op basis van het rooster voor de asielgehoren. Om per locatie een zo groot mogelijke diversiteit aan respondenten te bewerkstel-

5 Hawkins 1992, p. 6.

6 Vergelijk ook Kagan 1978 en Lipsky 2010 en in Nederland bijvoorbeeld Ringeling 1978 en Van der Veen 1990.

7 Havinga \& Terpstra 1999.

8 Hawkins 1992.

9 Lipsky 2010. 
ligen wordt in de selectie uitgegaan van een evenwichtige mix van geslacht, vooropleiding, ervaring en functieniveau.

\section{Slot}

In december 2011 ben ik als deeltijdpromovendus (één dag per week) aan dit onderzoek begonnen en heb bij het verschijnen van dit artikel net het veldonderzoek afgerond. Ik verwacht de eerste resultaten van het veldonderzoek binnen een jaar te kunnen presenteren en het onderzoek uiterlijk af te ronden in 2017.

\section{Referenties}

Cohen, J., 'Questions of Credibility: Omissions, Discrepancies and Errors of Recall in the Testimony of Asylum Seekers', International Journal of Refugee Law 2002-13(3).

Havinga, T. \& J.B. Terpstra, Uitvoering tussen traditie en management: Structuratie en stijlen van beleidsuitvoering, in: W. Bakker \& W.F. van Waarden (red.), Ruimte rond regels: Stijlen van regulering en beleidsuitvoering vergeleken. Amsterdam: Boom 1999, p. 40-67.

Hawkins, K., The Uses of Discretion, Oxford: Clarendon Press 1992.

Hawkins, K., "FATCATS" and the Prosecution in a Regulatory Agency: a Footnote on the Social Construction of Risk', in: J.F.J. Short \& L. Clarke (red.), Organizations, Uncertainties and Risk, San Francisco/Oxford: Clarendon Press 2001.

Kagan, R.A., Regulatory justice: implementing a wage-price freeze, New York: Russell Sage Foundation 1978.

Kelly, T., 'The legalization of human rights and the protection of torture survivors: asylum, evidence and disbelief', in: M. Dembour \& T. Kelly (red.), Are Human Rights for Migrants? New York: Routledge 2011, p. 184-198.

Lipsky, M., Street-level bureaucracy: dilemmas of the individual in public services, New York: Russell Sage Foundation 2010.

Ringeling, A.B., Beleidsvrijheid van ambtenaren: het spijtoptantenprobleem als illustratie van de activiteiten van ambtenaren bij de uitvoering van beleid, Alpen aan den Rijn: Samson 1978.

Veen, R.J. van der, De sociale grenzen van beleid. Een onderzoek naar de uitvoering en effecten van het stelsel van sociale zekerheid, Leiden/Antwerpen: Stenfert Kroese Uitgevers 1990. 